UDC: 338.48.(379.8)

JEL : 0.L 83.M 31.M 37

Alla L evitskaya

Dr. (H abil.), Assoc.Prof.

Comrat State U niversity, Department of E conomics

(Comrat, Moldova)

Nadejda Y anioglo

D octor of Economics, lecturer

Comrat State U niversity, Department of E conomics

(Comrat, M oldova)

\title{
DIGITAL MARKETING TECHNOLOGIES AS AN EFFECTIVE TOOL FOR PROMOTION OF TOURISM IN THE REPUBLIC OF MOLDOVA
}

The article notes that tourism is one of the most important driving forces of the world economy and one of the main sources of employment. At the same time, in the Republic of Moldova, this sector, despite the presence of quite significant tourism potential. A critical analysis of the state of the tourism industry of the Republic allows us to assert about its initial stage of development. The problem of management and promotion of the tourism product of the Republic of M oldova remains underdeveloped and requires methodological development. In this regard, one of the most relevant ways of effective promotion and development of this industry can be the wider use of digital marketing technologies in tourism. The article discusses the main determinants of digital marketing and their importance for the tourism industry in Moldova. promotion.

Keywords: digital marketing, tourism, tourism industry, tourism product, tourist flow, Internet

\section{DOI: $10.15276 / m d t .2 .3 .2018 .5$}

Statement of the problem in general form and it's connection with important scientific or practical tasks. Tourism has entered the 21 st century as the most dynamic sector of international trade in services. High rates of its development, large amounts of foreign exchange earnings actively affect various sectors of the economy. Currently, tourism is one of the most important driving forces of the economy and one of the main sources of employment. It has improved the lives of millions of people around the world [4].

According to the latest data from UNWTO World Tourism Barometer, the international tourism performance for 2017 is the highest in the last 7 years. Thus, the number of international tourist arrivals in 2017 increased by 7\% and reached a total of 1322 million. This strong momentum is expected to continue in 2018 at a rate of $4-5 \%$ [8].

The Republic of Moldova, according to the travel \& Tourism competitiveness Index 2017, compiled by experts of the world economic forum (WEF), based on the analysis of the situation in 136 countries of the world, took the last place among the countries in the field of travel and tourism among the countries of the former Soviet Union, Moldova is located on the 117 place in terms of attractiveness for tourists, in the neighbourhood with Ethiopia and Algeria, falling by six positions compared to the indicators of 2016 of this study. The ranking took into account such factors as security, infrastructure, cultural and natural diversity, openness, and prices. At the same time, Ukraine takes 88th place in the rating, Russia - 43, Romania - 68 [9].

(C) 2017 The Authors. This is an open access article under the CC BY license

(http://creativecommons.org/licenses/by/4.0/)

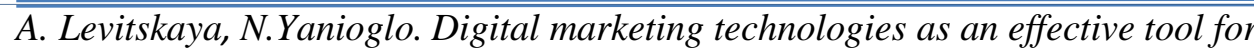
77

promotion of tourism in the republic of M oldova 
The situation in Moldova is also poorly assessed in terms of the level of tourist services - the Republic takes 105th place. It is gratifying to note the high level of Moldovan health care and sanitary standards (34th place), as well as the acceptable price level - 32 position [7].

Analysis of the latest research and publications, which initiated the solution of this problem and on which the author relies. In order to make more effective using of the tourism potential of the Republic of Moldova, in 2014 the tourism development Strategy «Tourism2020» was adopted (Annex No. 1 to the resolution of the Government of the Republic of Moldova No. 338 of 19 may 2014).

Highlighting the previously unresolved parts of the general problem to which the article is devoted. However, to date the most important and at the same time underdeveloped, requiring methodological development, is the problem of management and promotion of the tourism product of the Republic of Moldova.

Formulation of the purpose of the article (statement of the problem). In view of the above, the purpose of this article is to describe the current state of the tourism industry of the Republic of Moldova and to suggest ways of development in terms of digital marketing technologies.

The empirical base of the study was the tourism industry of the Republic of Moldova.

Statement of the main material of the research with full justification of the scientific results obtained. The law on the organization and implementation of tourism activities in the Republic of Moldova No. 352-XVI of 24 November 2006 defines tourism as one of the priority areas of the national economy [1]. At the same time, in the Republic of Moldova, this sector, despite the presence of quite significant tourism potential, is poorly represented.

Among the main disadvantages of this industry in Moldova are the following: most forms of tourism (cultural, gastronomic, social, sports, and automobile, weekend, urban, nostalgic and environmental) are not used enough by travel agencies. There is no strategy to attract new consumers to the tour market; the level of information on tourism potential and services is very low; the tools to inform and promote tourism are insufficient; with the exception of Chisinau is missing tourist information centres, etc. [2]. All these shortcomings have a serious effect on inbound tourist flow, which graphically represented in fig 1 .

Figure 1 shows that the basis of the tourist flow of Moldova is Moldovan citizens traveling abroad - on average, a little more than 150 thousand people a year. In 2017, 229.3 thousand tourists went abroad through travel agencies and tour operators, which is $29.4 \%$ more than in 2016. The majority of Moldovan citizens went abroad for holidays (98.9\%). Citizens of Moldova preferred to travel mainly to Turkey (35.7\%), Bulgaria (23.4\%), Romania (13.6\%), Greece (10.3\%), Egypt (4.4\%), Ukraine (3.3\%), Spain (1.4\%), Italy (1.1\%), Montenegro and the Czech Republic (1.0\%).

In second place for the period 2010-2017years are participants of domestic tourismabout 40 thousand people a year. The number of tourists participating in domestic tourism in 2017 amounted to 38.1 thousand people, which is $7.7 \%$ less than in 2016 . The movement of Moldovan residents within the country was organized mainly by tourism agencies located in Chisinau municipality (45.8\%), Centre of Republic (27.2\%) and the South (24.1\%). In 2017, $43 \%$ of foreign tourists and $57 \%$ of Moldovan tourists visited the collective structures for the reception of tourists with accommodation functions. 


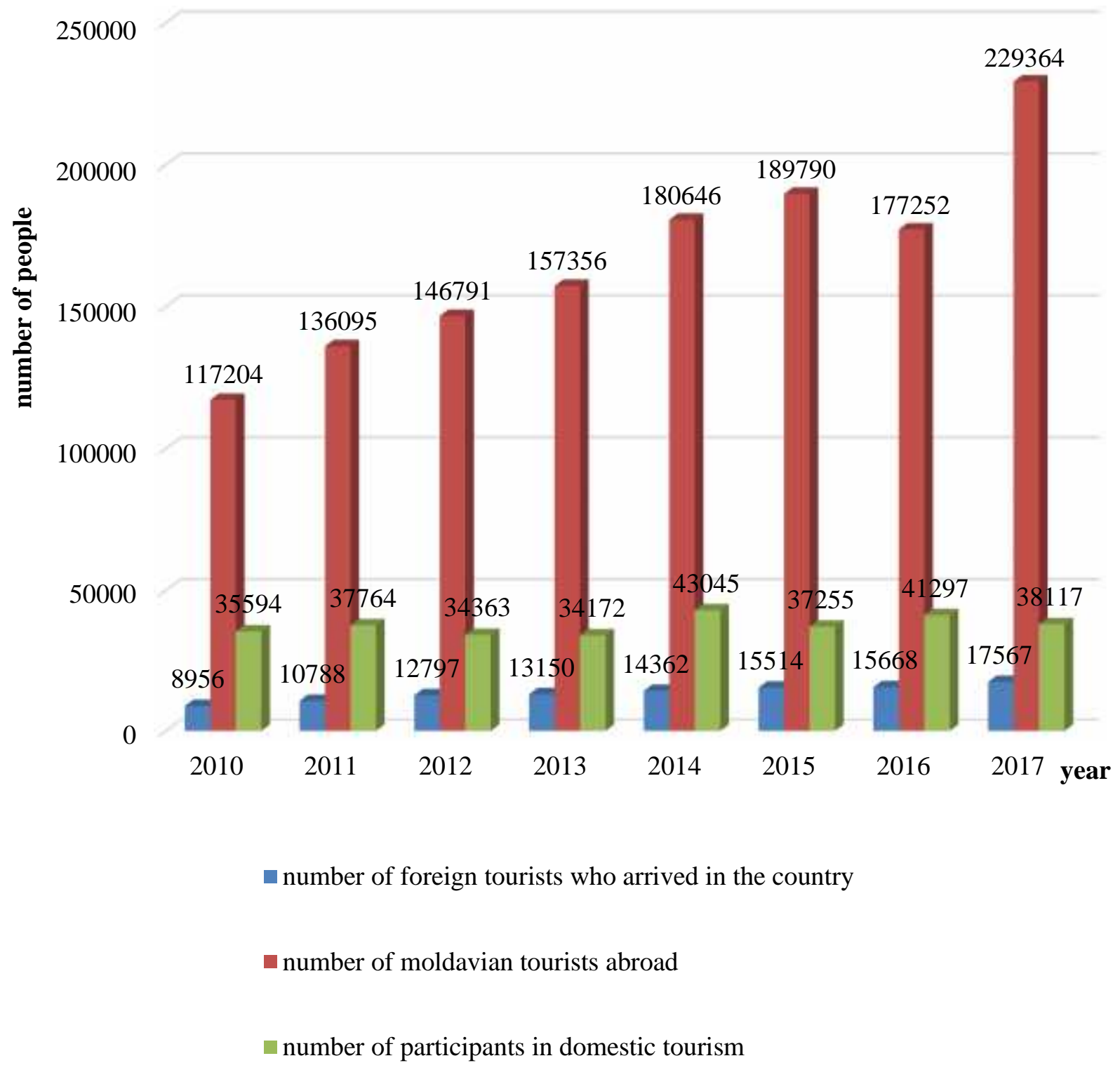

Figure 1 - Dynamics of tourist flow in the Republic of Moldova for the period 2010-2017 [6]

The number of foreign tourists who entered the country for the period 2010-2017 years is much lower - an average of 13 thousand people a year or about $8 \%$ of the number of travellers. Of the 17.5 thousand foreign tourists who visited the Republic of Moldova in 2017 and use the services of travel agencies and tour operators, $78.3 \%$ were on vacation, $17.2 \%-$ business and professional purposes. Among $4.5 \%$ of tourists who come for treatment, the majority choose dental services because of lower prices.

According to the Data of the National Bureau of Statistics of the Republic of Moldova in 2017, travel agencies and tour operators provided tourist services to 285.0 thousand tourists, which is $21.7 \%$ more than in 2016 . The increases of number of tourists were due to the increase in the number of participants of outbound tourism $(+29.4 \%)$ and inbound tourism $(+11.7 \%)$.

Consider the structure of the tourist flow that used the services of travel agencies and tour operators. 
According to the data of fig. 2, it can be noted that of all tourists entering the territory of the Republic of Moldova through travel agencies and tour operators in the period 2010-2017 visited from the CIS countries (about 23-25\%), about 75\% - tourists from other countries.

16000

14211

14000

\section{0}

S
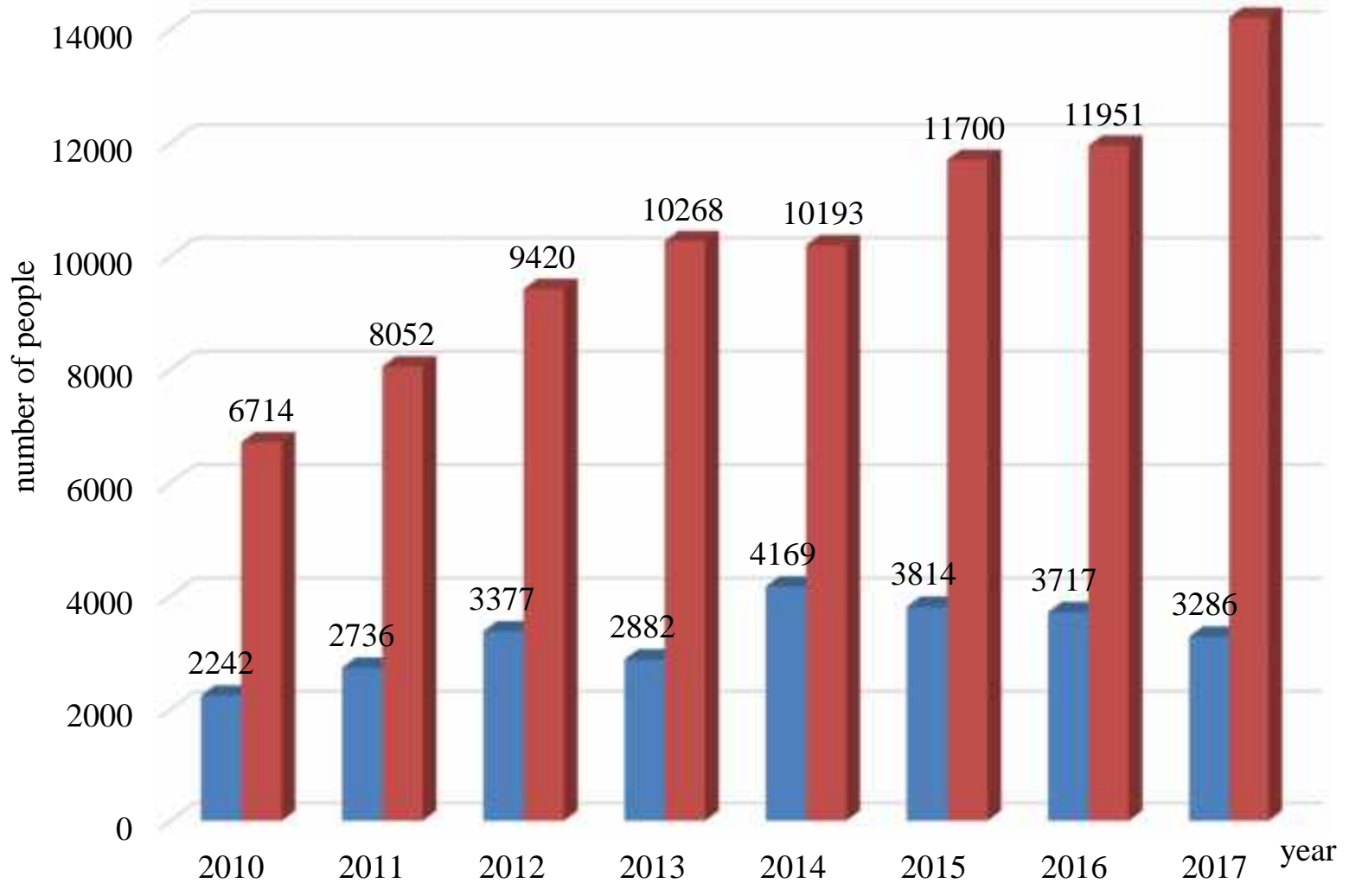

\footnotetext{
$\square$ CIS countries - total $\quad$ Other countries - total
}

Figure 2 - The number of tourists who arrived the Republic of Moldova through travel agencies and tour operators in the period 2011-2017 [6]

We will analyze the number of inbound tourists who visited the collective structures of the Republic of Moldova in receiving tourists with accommodation functions in the period 2010-2016 (tab. 1).

For example, in 2017, in the total number of foreign tourists arriving in the Republic of Moldova, more significant weight ratios are among the citizens of Romania (24.6\%), the Russian Federation (8\%), Ukraine (13.5\%), Germany (5\%), and Italy (5\%). Unfortunately, these statistics cannot indicate the high attractiveness of Moldova for the citizens of the mentioned States. In this regard, one of the most relevant ways of effective marketing of this industry in the Republic of Moldova, according to the authors, may be a wider and more effective use of digital technologies in tourism. 
Table 1 - Number of foreign visitors to the Republic of Moldova by country of origin [6]

\begin{tabular}{|c|c|c|c|c|c|c|c|c|}
\hline Indicator & 2010 & 2011 & 2012 & 2013 & 2014 & 2015 & 2016 & 2017 \\
\hline $\begin{array}{l}\text { Total number of foreign } \\
\text { visitors, people }\end{array}$ & 63593 & 75000 & 88956 & 95640 & 93897 & 94381 & 121340 & 145165 \\
\hline \multicolumn{9}{|c|}{ Including from such countries as (people): } \\
\hline Russian Federation & 6484 & 7840 & 9244 & 11003 & 8368 & 9054 & 9705 & 12999 \\
\hline Ukraine & 6083 & 7194 & 8216 & 9287 & 10951 & 13503 & 16422 & 17887 \\
\hline Bulgaria & 1384 & 1163 & 1373 & 1657 & 1837 & 1646 & 1848 & 2207 \\
\hline France & 1479 & 2130 & 2103 & 2256 & 2140 & 1882 & 2492 & 2952 \\
\hline Germany & 3468 & 3863 & 5520 & 5934 & 4672 & 3964 & 5602 & 6701 \\
\hline Italy & 3942 & 4447 & 5001 & 5084 & 5143 & 4677 & 5086 & 5987 \\
\hline Poland & 1390 & 1872 & 2295 & 2677 & 2453 & 2154 & 3511 & 4215 \\
\hline Romania & 15403 & 16097 & 17549 & 21030 & 22624 & 23884 & 29902 & 35950 \\
\hline Turkey & 2538 & 2781 & 5798 & 4600 & 3523 & 4118 & 4467 & 5815 \\
\hline $\begin{array}{l}\text { Share of countries } \\
\text { represented in the table to } \\
\text { the total number of foreign } \\
\text { visitors, \% }\end{array}$ & 66,3 & 63,2 & 64,2 & 66,4 & 65,7 & 68,7 & 65,1 & 65,2 \\
\hline
\end{tabular}

With the advent of Internet technologies, marketing rules have been revised worldwide. The Internet has changed the way consumers interact with brands, as interactivity has created a new dimension of communication between all market participants. This completely transformed the policy of promotion in the economy, and digital marketing has become one of the key areas for business worldwide.

The main reason for success of digital marketing compared to traditional is the fact that the first allows companies to track consumer behaviour in real time. Each campaign launched in digital form, can be tracked from the point of view of its scope, participation and conversion. This gives a whole new meaning to marketing research in the field of customer needs.

Internet marketing includes a number of features conditioned to the fundamental differences of the digital environment:

- Continuality (continuity) in time and space. The Internet operates 24 hours a day, 365 days a year, almost anywhere in the world, hence the same continuality, potentially, has any marketing campaign conducted on the Internet;

- Universality. Network information exchange protocols (HTTP, SMTP, FTP, etc.) are equally executed anywhere in the world;

- Multichannel, characterized by the many digital channels of reporting [5].

- Speed. In the time it takes to get the results of a single mailing or print advertising, online marketing allows you to run multiple online campaigns via email, social networks and see the results very quickly;

- Cost. The cost of printing, mailing and advertising space in traditional marketing is much higher than the cost of reaching customers on the Internet;

- Analytics. Perhaps the biggest advantage of Internet marketing is the possibility of advanced Analytics. With the help of various tools, it is possible to measure the effectiveness of almost all aspects of campaigns and promotions, which allows you to eliminate those that do not work, and improve those that are effective.

Internet marketing includes the following elements of the system (fig. 3). 


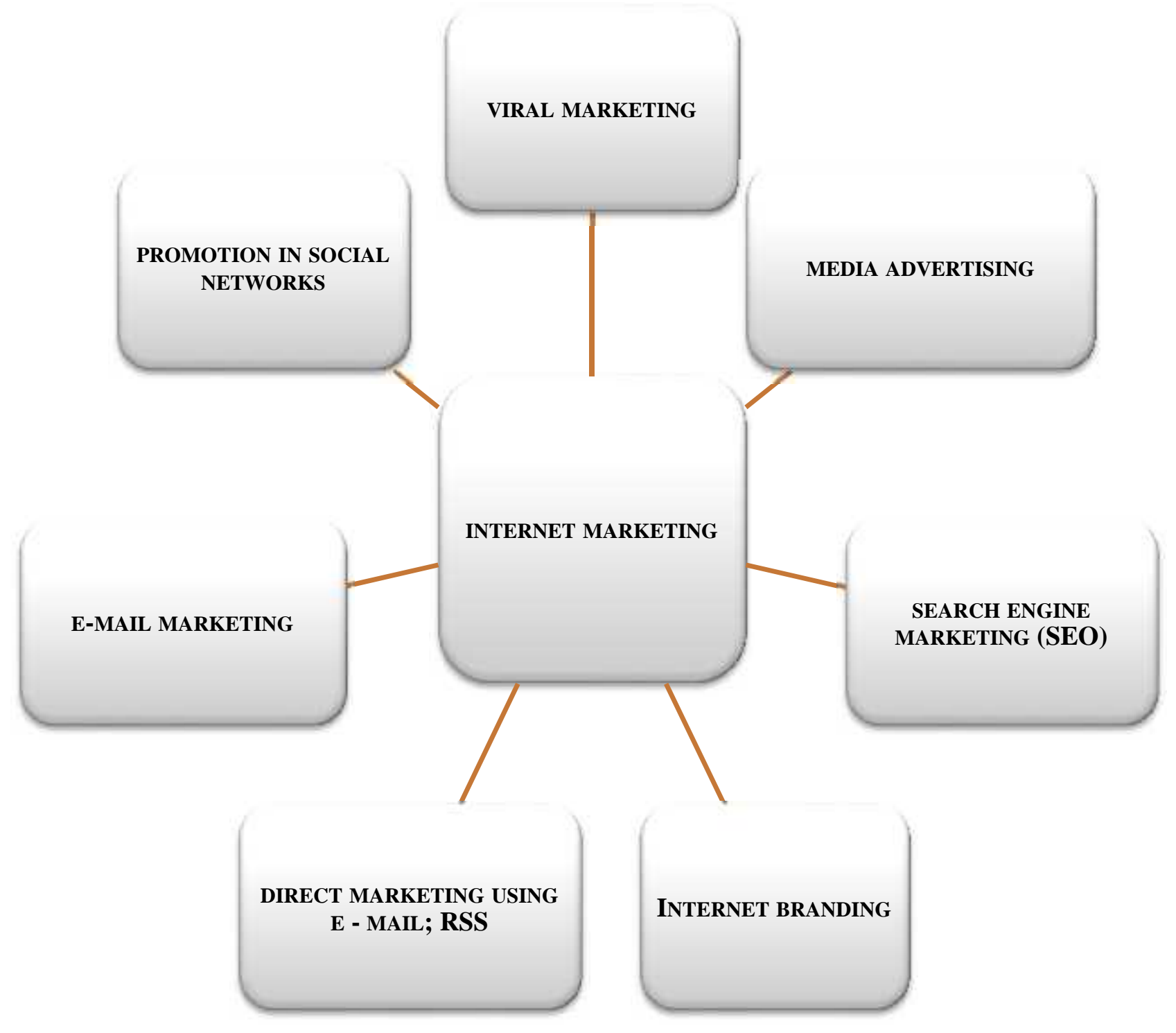

Figure. 3 - Elements of Internet marketing [5]

The tourism industry of the Republic of Moldova can be recommended to use the following tools of digital marketing:

1. Digital presentation on the web sites of the National Agency for tourism of the Republic of Moldova, General Directorate of Culture and Tourism (ATU Gagauzia), tourist operators and others. In the basis of digital presentation lies a panorama of tourist destination. Looking through 3D panoramas, a potential tourist gets the opportunity to verify the accuracy of the description of the tourist object. In addition, virtual tours are more informative compared to promotional brochures, which causes more emotions among the participants and contribute to the purchase of the tour.

2. Mobile application. Mobile applications are convenient because they allow tourists to organize their own vacation. When installing the app on your Smartphone, a tourist can easily access information about their flights, bookings and travel routes, which is a great incentive for the market. 
It should be noted that the Republic of Moldova has little progress in this area. So, at the end of November 2017, in the test mode, the application for wine tourism «Moldova Wine Route» was launched. The application contains information about the 12 most important wineries with the presentation of services and the most popular 10 wines of each. In addition, in the application you can find recommendations on the most popular wine bars and wine shops of the Moldovan capital [3].

3. Exclusive offers via email and social networks. Effective advertising activity of organizations in social networks is quite a new phenomenon at the same time very effective due to the large audience coverage, time spent by users in social networks, the possibility of direct contact with customers and the cost of advertising. Despite the fact that making exclusive offers travel company will earn less, it will help to create a wide base of loyal customers.

\section{Conclusions from this research and prospects for further developments in this}

area. Digital marketing has now become an integral part of any business, regardless of its size and type. The growing role of digital marketing has influenced how companies promote their offerings to both existing and new customers. The need for digital marketing has been felt more than ever in the tourism industry, where customers have instant access to all kinds of information about the latest offers and best prices. The wider and more effective use of Internet marketing in the tourism sector is of great interest not only for individual tourism companies, but also can generally affect the development of the tourism industry in the Republic of Moldova.

1. Law on the organization and implementation of tourism activities in the Republic of Moldova 352XVI. (2006, 24 November). Retrieved from: lex.justice.md/document_eng.php?id =A5028999:391F4418 [in Moldovan].

2. State Information Agency «MOLDPRES». The mobile application "Moldova Wine Route" was launched on the tourist market. www.moldpres.md Retrieved from: www.moldpres.md/en/news/2017/11/28/17009292.

3. Mirsayakova, V.A. (2016). The Importance of Tourism in the World Economy. Young Scientist, 5, 17-19 [in Russian]. Retrieved from: moluch.ru/archive/109/26821.

4. Mikolaychuk, A.A., \& Lankovskaya, E.K. (2016). Internet marketing as an effective tool for promoting tourist destinations in the Crimea. Tavrichesky scientific observer,1 (6), 39-43 [in Russian].

5. National Bureau of Statistics of the Republic of Moldova. Statistical Data Bank. statbank.statistica.md.

6. Monitorul Fiscal. International experts: Moldova has become less attractive for tourists. monitorul.fisc.md Retrieved from: monitorul.fisc.md/mic/mezhdunarodnye-eksperty-moldova-stalamenee-privlekatelnoy-dlya-turistov.html.

7. UNWTO World Tourism Barometer. 2017 International Tourism results: the highest in seven year. tourlib.net Retrieved from: tourlib.net/wto/UNWTO_Barometer_2018_01.pdf.

8. World Economic Forum. The Travel \& Tourism Competitiveness Report 2017. www.weforum.org Retrieved from: www.weforum.org/reports/the-travel-tourism-competitiveness-report-2017.

9. Oklander, M.A. (2002). Problemy formuvannia marketynhovoi systemy krainy [Problems of the formation of the country's marketing system]. Kyiv: Naukova dumka [in Ukrainian].

10. Oklander, M.A. (2003). Makromarketynh: marketynh v sektori zahalnoho derzhavnoho upravlinnia [Macro Marketing: Marketing in the General Government]. Marketynh v Ukraini [Marketing in U kraine], 6 (22), 31-37 [in Ukrainian].

11. Oklander, M.A., Oklander, T.O., \& Yashkina, O.I. (2017). Tsyfrovyi marketynh - model marketynhu XXI storichchia [ Digital M arketing - The M arketing M odel of the 21st C entury]. Oklander, M.A. (Ed.). Odesa: Astroprint [in Ukrainian]. 
Левит ська Алла Пет рівна, докт ор хабіліт ат економічних наук, конференціар університ ар, Комрат ський держ авний університ ет, кафедра економіки (Комрат , М олдова).

яніогло Надія Пет рівна, докт ор економічних наук, викладач, Комрат ський держ авний університ ет, кафедра економіки (Комрат , Молдова).

\section{Цифрові т ехнології маркет ингу як ефект ивний інст румент просування т уризму в Республіці Молдова.}

у ст ат т і наголошуєт ься, що в даний час т уризм являє собою одну з найваж ливіших рушійних сил світ ової економіки і один з головних дж ерел зайнят ост і. У т ой ж е час, в Республіці Молдова ця галузь, попри наявніст ь досит ь значного т урист ичного пот енціалу, предст авлена слабо. Крит ичний аналіз ст ану т урист ичної галузі Республіки дозволяє ст вердж уват и про ії почат кову ст адію розвит ку. С лаборозвиненою залишаєт ься проблема управління т а просування т урист ичного продукт у Республіки Молдова, що вимагає мет одологічних розробок,. у цьому зв'язку одним з найбільш акт уальних шляхів ефект ивного просування т а розвит ку даної галузі мож е вист упит и більш широке заст осування цифрових т ехнологій маркет ингу в т уризмі. у ст ат т і розглядают ься основні дет ермінант и цифрового маркет ингу т а їх значення для індуст рії т уризму М олдови.

лючові слов : цифровий м ркетинг, туризм, туристичн г лузь, туристичний продукт, туристичний потік, інтернет просув ння.

Received to the editor August 1, 2018. 